Research Paper

\title{
Diversity As A Problematic Predictor Of Organizational Performance: Issues Of Context And Expectations
}

\author{
KeVin T. WAYne \\ Corresponding author: kwayne@rivier.edu \\ Rivier University, USA \\ JONATHAN G. MCCOSH \\ Colby-Sawyer College, USA
}

\section{Abstract}

Diversity continues to confound scholars with its range of interpretations, debates about its benefits, and hypothesized impacts on organizational performance. Management practitioners often encounter difficulty in dealing with diversity initiatives within organizations. A review of the literature reveals equivocal results when studying the elusive relationship of diversity and performance. Using Hofstede's seminal work on culture as a starting point while recognizing the existence of subcultural variations, we challenge a variety of diversity arguments for their reported influence on performance outcomes and find that organizational context matters a great deal. Much of the literature emphasizes high expectations for diversity as a condition and predictor of better organizational performance. The paper points out the complexity and diversity of diversity variables that include gender, race, class, nationality, functional skills, and perspective. The hopeful orientation and high level of expectations of much diversity research are critiqued. The paper offers explanations for the over-generalized and problematic nature of diversity as an explanatory variable and concludes with suggestions for future study.

Keywords:Culture, Diversity, Context, Expectations, Organizational performance, Teams, Affinity, Poststructuralism

\section{Introduction}

Seldom do academicians and practitioners wrestle with a phenomenon as multi-faceted and conditional as diversity. Press accounts of the impressive benefits of diversity are alarmingly commonplace, such as these broad claims from a recent Wall Street Journal reporter:

Research has established the business case for diversity. This isn't an argument about redressing historical inequities or even present-day fairness. More diverse companies have better financial returns, are more innovative 
and are just plain smarter than their more homogenous competitors (Mims, 2017, p. B1).

Similarly, a Los Angeles Times headline echoes a popular belief with "Women on Board: Firms with Female Directors Do Better, Study Says" (Hsu, 2012). Furthermore, many scholars have leaned toward a more hopeful (versus disinterested) orientation when extolling positive outcomes associated with diversity (Wayne, 2017). Indeed, today's conventional wisdom contends that diversity — which carries multiple, contextual meanings-is a strong net positive for work groups and organizations. Few will argue with the need to further study diversity in more specific organizational contexts, especially given the significant resources spent implementing diversity programs. Diversity training is a lucrative area for management consultants, although much of the approximately $\$ 8$ billion spent annually in the U.S. on workplace diversity training is not thought to have achieved desired results (Wharton, 2016). In a review of diversity-related policies in 708 private organizations, researchers found diversity training to be largely ineffective and often the cause of resentment among employees (Kalev, Kelly \& Dobbin, 2006). Dobbin and Kalev (2016) cite outdated diversity programs that, in some cases, activate bias instead of mitigate it.

Evidence from the literature indicates lackluster outcomes with regard to performance in the presence of diversity variables (Byron \& Post, 2016; Dezso \& Ross, 2012; Jayne \& Dipboye, 2004; Kochan et al., 2003; Post \& Byron, 2015; Rhode \& Packel, 2015; Sivasubramaniam et al., 2012; van Knippenberg et al., 2007). Reputable practitioner-oriented publications, including newsletters from the Wharton School and the European Institute of Business Administration (INSEAD), have reported on several meta-studies indicating weak or neutral outcomes in organizational performance as a result of diversity being present in its various forms (INSEAD, 2008; Wharton, 2017). This inconsistent story regarding performance benefits of diversity leads us to contemplate the stress experienced by first line supervisors, team leaders, middle managers, corporate officers and directors when confronted with issues of workplace diversity. The confusion over diversity's value-combined with its contextual definitions and corporate mandates on inclusion activities - has made the already difficult tasks of selecting and managing people all the more challenging.

While it is often deemed politically incorrect to challenge pro-diversity programs, the global consultancy giant Deloitte LLC has recently done just that. Deloitte has begun phasing out employee affinity groups, often referred to as employee resource groups (ERGs). ERGs include employees that share some minority characteristic, such as being LGBT, black, Hispanic, or female. Deloitte employees have reported that ERGs often result in more insulation of minority groups and unintentionally hamper inclusion efforts. Deloitte is shifting to "inclusion councils," hoping to make progress on diversity issues while breaking down silos (Green, 2017).

This paper reviews extant literature in the diversity-performance domain for a dispassionate look at the relationship between diversity and the performance of teams and organizations. We also explore the sociopolitical forces that drive much of the research in this area. We frame the terminology under study to encompass the meaning of cultural diversity in a general context, as well as with regard for more nuanced diversity variables. In particular, we review the relationships between performance outcomes and various independent variables such as gender, race, class, nationality, functional skills, and perspective. We also examine the moderating influences of context and expectations on the diversity-performance relationship. This paper adds to the high rate of scholarly activity seeking new models and frameworks to better understand diversity in its many forms as it relates to team and organizational performance. We conclude our discussion with several research questions for future study. 


\section{Problem Statement}

To be clear, we concur with many scholars that much of the unequal representation in the workplace has been driven by historical biases, stereotyping, and social networks (Kalev et al., 2006) yet we do not possess the bandwidth in this paper to focus on causation from these factors. We see great social value in diversity, although much of this value is either difficult or impossible to measure conventionally or empirically. However, when focusing on the diversity-performance conundrum, several questions arise from our review of the literature, including: Is the drive for more equality, fairness, and proportional representativeness overpromising the benefits-and to some extent underestimating the challenges - of diverse workplaces? How important is the specific context of the work environment when determining the impact of diversity? Would diversity's benefits be more actualized by employing more subtle and less examined aspects of diversity (i.e., personality- and cognitive-oriented factors versus more salient, traditional measures like age, gender, or race)? Why has group, organizational, regional, and national performance been prioritized as outcome variables with regard to the study of diversity? Has the need for a compelling "business case" justification for diversity clouded the research efforts of scholars? Is the disinterested nature of organizational scholarship at risk given the social justice and policy advocate's desire to demonstrate performance advantages gained from diversity (Eagly, 2016; Wayne, 2017)? For example, the global consulting firm McKinsey \& Company regularly publishes a Diversity Matters Report that extolls the firm's position that diversity is a must for organizations desiring better performance (Hunt, Layton \& Prince, 2015). Yet, when examining the data, the clear case for diversity as an indicator of superior performance is far from a given.

Methodologically, we begin with a foundational review of cultural frameworks due to their influence on diversity research. We then discuss relevant theories and review several studies from the diversity-performance domain. Our selection of studies, while broad but not entirely exhaustive due to the vast amount of literature, is predicated on research that may: a) include provocative or suspect claims of diversity's benefits for performance; b) communicate reputable scholarship that indicates diversity does not improve performance; or c) address context-specific schema that examines specific conditions that moderate the diversity-performance dynamic. Our selection criteria is not focused on a moral or deontological perspective but is instead guided by a utilitarian approach, meaning research that is primarily concerned with the business case for diversity. Given the broad scope of our inquiry, our selection criteria does not exclude studies focused solely on team (internal) or organization (external) performance outcomes.

We present an analysis and narrative where diversity, in its many simple as well as complex forms, may be beneficial, detrimental, and often irrelevant in terms of affecting performance. We endeavor to show that context and the biased expectations of scholars and advocates impact research results and interpretation of these results. As Berrey (2015) wisely cautions, "the word [diversity] wears a halo and also a haze." (p. 26).

\section{Theoretical Foundation of Cultural Diversity and Additional Concerns}

When studying diversity in organizations we should first delineate the intertwined terms of diversity and culture. While diversity is generally defined as involving variety or someone/something being different from the rest of the group in some way, its presence in organizations and the greater culture is generally regarded with positive sentiment and rhetoric. Diversity is often narrowly characterized in salient terms such as age, race, and gender. Berrey (2015) points out how some diversity proponents lambast non-diverse organizational cultures as "simple or bland 
homogeneity." Diversity has indeed become "difficult to discredit" (p. 42), leaving some to wonder if excellence is even possible without diversity being present. And again, our aim is not to refute the social justice virtues of diversity or equality, but instead our objective is to elucidate that diversity is not a necessary, all-powerful variable that ensures better organizational performance.

Culture, in contrast to diversity, is based more on commonality, elements of sameness, and shared beliefs, values, meanings, traditions, behavior, and characteristics. A foundational framework for studying diversity in culture was developed by Hofstede (1980; 1993). Hofstede et al. (2010) defined organizational culture as "the collective programming of the mind which distinguishes the members of one group or category of people from another." (p. 344). The concept of cultural diversity invites both cohesion and conflict given that culture represents similarities while diversity involves differences or otherness. It stands to reason that when people with various cultural backgrounds interact, their cross-cultural differences may manifest themselves through communications issues. With the increase in globalization and the growing number of international business interactions, there are ample opportunities for cross-cultural conflicts. A number of studies, using a variety of research instruments, have shown a greater likelihood of success when a multinational corporation matches specific business practices to specific national cultures, rather than using the same practices worldwide (Schuler \& Rogovsky, 1998).

Hofstede, employing his Dimensions of Culture model to measure values, conducted the seminal research in this field. Briefly, the four original dimensions of this framework included: power distance (from small to large); collectivism versus individualism; femininity versus masculinity; and uncertainty avoidance (from weak to strong) (Hofstede, et al., 2010). Additional research focused on the area of cross-cultural negotiations (Morris et al., 1998). This approach views the cultural situations of different countries with the assumption that these situations can be quantified, and that theoretical models can be developed to better explain how cross-cultural interactions occur. With this understanding, researchers can better explain ensuing communications problems. Proponents of the anthropological perspective have criticized this approach, feeling that the unit of analysis of there being universal cultural commonalities is not accurate and therefore cannot be treated as a valid construct. They find that the measurement instruments used by Hofstede and subsequent researchers have focused on subjective value statements rather than an anthropologic definition of culture, which is based upon the interpretation of symbols and group practices (Brannen \& Salk, 2000).

Although a number of cross-cultural studies have been conducted, it has been asserted that each of these was narrowly focused in scope, comparing only a few cultural dimensions among a limited set of cultures. Therefore it may not be valid to use these studies for making generalizations regarding cross-cultural communication (Newman \& Nollen, 1996). Researchers further question whether this model can be applied to specific business situations among international corporations. Some believe that the linkages between national culture and the business environments within these cultures require further study before definitive conclusions can be reached (Lenartowicz \& Roth, 1999). Whereas the management and operational climate (i.e., the corporate culture) among businesses located in the same geographic location varies widely, it is questionable whether the variables associated with a single nationality would necessarily be applicable to the majority of businesses within that region (Brannen \& Salk, 2000).

A recent meta-analysis of 558 studies using Hofstede's cultural values framework found inconsistencies with interpretations of terminology as well as other problems caused by using country or nationality as a substitute for culture (Taras, Steel \& Kirkman, 2016). This same meta-analysis also concluded that the "illusion of homogeneity" may serve to galvanize widespread cooperation, but it does not allow for "country averages to act as proxies for cultural values of individuals or small groups from these countries." (p. 483). In a comprehensive analysis of commonly used methods 
for characterizing culture, Kivenzor (2015) noted how a "growing body of research criticizes the inconsistencies of the national culture concept, citing escalating cultural diversity of many countries." (p. 146). Relatedly, Cowen (2002) described globalization's role in creating a "diversity paradox" in which diversity increases within cultures but decreases across cultures. Over time, cross-cultural differences become less pronounced as the various artifacts of cultures are shared (e.g., goods, language, media, dress, traditions, business practices, etc.). Given this flux, Kivenzor (2015) highlights the dynamism of market and cultural change and warns of the use of static models that rely on generalizations beyond social groups and subgroups.

The Dimensions of Culture theory has been criticized for defining culture too broadly, reflecting that within a national culture there are usually several subcultures and that the subcultures display characteristics different from those of the dominant culture (Brannen \& Salk, 2000). Notably, Hofstede et al. (2010) acknowledges certain limitations, and contends, for example, that "Gender, generation, and class cultures can only partly be classified by the dimensions found for national cultures . . . [and they] should be described in their own terms, based on special studies of such cultures." (p. 46). The use of Hofstede's broad definition of culture also does not take into consideration intra-cultural variations as noted by $\mathrm{Au}$ (1999) that cites the need for additional independent variables to recognize if subcultures exist within the analysis of the cultural component. Schwartz (1999; 2006) also proposes the use of additional variables when conducting a value analysis of culture in order to account for unique cultural aspects of regional differences including societal norms. Leung \& Morris (2015) also support the expansion beyond analysis of cultural values, proposing that in-depth study of the norms and schemas within specific cultures and situations will lead to more robust explanations of behavior.

Another criticism, while not disputing the methodology of the theory itself, indicates that the use of traditional cultural frameworks could lead to the exacerbation of stereotypes about doing business in various countries. The stubbornly resilient nature of stereotypes is viewed as a barrier towards international communication, so the further use of this framework may be seen as detrimental rather than beneficial to international business (Goby, 1999). Indeed, not only has the literature revealed examples of decreased performance or lost productivity associated with diversity (Julian \& Ofori-Dankwa, 2017; Kochan et al., 2003; Stahl et al., 2010), there is also growing criticism that diversity efforts have weakened the cause for general equality in the workplace (Zanoni, 2014). Berrey (2015), with observations from a field study of a Fortune 500 consumer products firm, warns of how the "selective inclusion" of diversity initiatives leaves out many individuals, especially minorities from lower socio-economic classes within the organization. We concur that many organizations appear focused on highlighting diversity (or lack of it) at the more visible, upper levels. Organizations may engage in window dressing and public relations activities to enhance their diversity and multicultural posture with stakeholders, which the firms may promote to mask their lack of true commitment to more comprehensive acts of justice-be it economic justice or social justice.

Hofstede's model has also been criticized for "over-simplifying complex cultures, generalizing from a limited number of firms, assuming that cultures and social structures are static, and ignoring within-country heterogeneity." (Egan \& Bendick, 2008, p. 388). Indeed, Hofstede's initial work was narrow in that he used only one multinational corporation, International Business Machines (IBM), even though he drew large samples from over fifty different countries (Hofstede et al., 2010). Critics have questioned whether this particular corporation possessed unique characteristics which would prevent the replication of the same research design with other multinational organizations (Frijns et al., 2016).

Using the seminal work of Hofstede as the starting point, the background discussion above is provided to afford perspective towards the diversity-performance relationships under review in this article. We see many parallels between cultural values frameworks and diversity models with regard to the difficulty of dislodging mainstream 
thinking and arriving at new explanations for complex organizational phenomena. Next, we touch on the common theories employed in diversity-performance research and discuss how one theory in particular is developing to help scholars understand contextual influences on the diversity-performance relationship.

\section{Diversity and Performance}

Frustrated by historical inequities, diversity advocates have been at odds with homogeneity in the workspace, which is often modelled and explained (partly) by the similarity-attraction theory (Byrne, 1971; Newcomb, 1961). This model posits that people are more comfortable around others from similar backgrounds and cultures. These shared characteristics reduce the propensity for social and work conflict (Pfeffer, 1983; Sivasubramaniam et al., 2012; Williams \& O'Reilly, 1998). Indeed, well-aligned person-organizational fit has been shown to positively impact employee tenure and performance, revealing how employees are attracted to organizations that share the same values (Kristof-Brown $e t$ al., 2005; Sacco \& Schmitt, 2005). The similarity-attraction perspective as well as self-categorization (Turner, 1985) and social-identity (Hogg \& Abrams, 1988; Tajfel, 1981) theories take a negative view of diversity due to the disruption caused by dissimilar characteristics. Indeed, adaptive self-categorization and self-assembly demonstrate humanity's affinity for homogeneity and shared values. When it comes to surface-level characteristics, opposites do not necessarily attract. In contrast to these similarity-oriented theories that view diversity as disharmonious and potentially negative, the information-processing approach (Ancona \& Caldwell, 1992; see Mannix \& Neale, 2005) involves a positive outlook for diversity due to the benefits of cognitive experience and in observing how diversity produces positive outcomes (e.g., pooling of different functional skill sets, perspectives, and problem-solving approaches (Page, 2007), etc.).

Theory with specific intent to explain contextual influences on the diversity-performance relationship has begun to gather momentum. After their meta-analysis on team and organizational diversity, Jackson et al. (2003) remarked that the literature at the time displayed a "lack of strong theory to guide researchers who are concerned about acknowledging the role of context" (p. 821) and that there was "little theoretical clarity concerning how moderators influence the effects of diversity." (p. 816). van Knippenberg et al. (2004) proposed the categorization-elaboration model (CEM) that combines the social categorization and information-processing/decision making approaches to analyze team-oriented diversity-performance phenomena. Importantly, this model encompasses prior frameworks that were essentially polar opposites in their view of diversity's directional effect on group outcomes. It also takes into account conditional moderators that amplify or negate a diversity attribute's impact. Schneid et al. (2015) recommends the integration of cultural variables into the CEM framework for assessing normative fit when studying gender diversity. Notably however, we did not restrict our selection of studies to any one of the aforementioned theories or models due to the broad scope of our inquiry and narrative. Next, we discuss several works from the diversity-performance domain.

Empirically-derived results for the business case rationale for diversity are viewed as either mixed or equivocal by many researchers (Eagly, 2016; Klein \& Harrison, 2007; Kochan et al., 2003; Mannix \& Neale, 2005; Pletzer et al., 2015; Rhode \& Packel, 2015; van Dijk et al., 2012). One research team speculates that the binary nature of the business case and the social equality perspectives may simply be "incongruent" and locked in a "stalemate" (van Dijk et al., 2012). These same researchers go beyond this moral struggle by proposing a values and virtues based perspective for managing diversity, citing it as a "context-sensitive" approach.

Eagly (2016) presents a stern rebuttal to rampant claims of better performance outcomes related to a) more women on corporate boards; and b) demographically diverse work groups. For instance, after reviewing meta-analyses and 
extensive empirical evidence, Eagly concludes that performance attributed to the proportion of women on boards is "mixed" and not indicative of causation. She criticizes claims of a robust business case due to the number of women on boards as "supported by citations of the least informative studies, which are containing only simple group comparisons." (p. 203).

In one of the more comprehensive studies in this domain, Gomez-Mejia and Palich (1997) conducted a longitudinal study looking at Fortune 500 Companies over a ten-year time frame seeking to find a positive relationship between cultural diversity and financial performance. Hofstede's models were used as a primary basis for this research. A sample of 442 firms was used for the initial five-year analysis, which then continued with 228 firms (52\%) for the second five-year analysis. Their conclusion revealed no relationship and no statistical significance, even when the data was broken down by geographic and industry sector groupings. More recently, Frijns, Dodd, and Cimerova (2016) sought to find positive financial performance for companies that had cultural diversity on their corporate boards and also utilized Hofstede's models. The conclusion was the opposite of what the researches had looked for, concluding that "cultural diversity in boards negatively affects firm performance, indicating that the frictions imposed by cultural diversity outweigh the positive advantages." (p. 35). Estelyi and Nisar (2016) promoted the notion of board diversity due to the belief that a diverse body of decision makers would be better able to serve a diverse group of stakeholders. But while improved financial performance was listed among their assumptions, it was not supported by the data.

Perhaps scholars have become too comfortable with Hofstede's explanation of international cultures as they relate to organizations and work? Do scholars need to refrain from or at least remodel Hofstede's widely used assumptions in order to accommodate the intricacies of so many diversity-related measures? Kivenzor (2015), while studying marketing strategies for emerging markets, remarked about a growing trend in the literature that noted shortcomings with the Hofstede framework. Given the disparity in definitions and approaches to diversity research, some scholars have described the domain as "murky," and remark that "the diversity literature itself is so diverse" (Harrison \& Klein, 2007, p. 1200). Regarding the tricky composite of cultural diversity, we view this as a parent or umbrella variable of sorts. Unless thoroughly scrutinized, culture and diversity constructs are too often viewed in isolation and may be susceptible to over-generalization, yielding little support for explaining the effects of diversity on business or team performance. However, the intricate componentry of cultural diversity offers rich, distinct variables that interact within a variety of contexts, and are in need of further study.

\section{How Context Matters}

The difficulty in establishing agreement on the influence of diversity on performance has led many researchers to test the impact of context. While context can be broadly thought of as the conditions or circumstances surrounding something of interest, we prefer the more formal definition from Johns (2006), defining context as "situational opportunities and constraints that affect the occurrence and meaning of organizational behavior as well as functional relationships between variables." (p. 386). Akin to our own interpretation of the diversity-performance literature pertaining to work teams, Mannix and Neale (2005), in their comprehensive analysis, concluded that:

Surface-level social-category differences, such as those of race/ethnicity, gender, or age, tend to be more likely to have negative effects on the ability of groups to function effectively. By contrast, underlying differences, such as differences in functional background, education, or personality, are more often positively related to performance-for example by facilitating creativity or problem solving-but only when the group process is carefully controlled (p. 32). 
Note the above conclusion's contextual qualification of "carefully controlled" conditions when determining a positive diversity-performance connection. Furthermore, the tendency to isolate the more pronounced attributes of diversity identification (e.g., race, gender) as a method of social categorization leads to more stereotyping (Mannix \& Neale, 2005).

In another example of the importance of context, Byron and Post (2016) concluded that female board representation increased social performance of firms within the context of operating in countries with higher gender parity and stronger shareholder protections. Incidentally, we view the rise in studies focused on the gender-board of directors dynamic as indicative of picking the low hanging fruit for positive performance results with diversity (Wayne, 2017). Gender may be a convenient screen that supersedes race and other socio-cultural attributes, leading to the presumption of an easier path to desired (i.e., positive) performance-oriented results.

In a study hypothesizing that female senior managers in Standard \& Poor's 1500 firms will have a positive impact on performance, Dezso and Ross (2012) concluded that this was true but "only to the extent that a firm's strategy is focused on innovation," and rationalized this positive outcome was due to the "human capital advantage" of female executives (p. 1085). We view this particular interpretation of results as somewhat presumptuous and an example of an over-reaching justification that, in the end, does not necessarily advance the cause of truth seeking in organizational research.

Regarding gender-related influences, we find it useful here to include the work of Schwartz and Rubel (2005) that tested value priorities among gender differences across 73 countries. While not testing for performance outcomes, this study nevertheless found that women considered the values of benevolence and universalism more important than men did, while men scored power, stimulation, achievement, and self-direction more essential than women. While the gender differences were consistent across numerous cultures, the effect of gender was small and explained much less of the variances than did culture itself. Both counter and complimentary to our argument for the importance of contextual influences, the transituational nature of individual values (e.g., across cultures, women value benevolence more than men (Schwartz \& Rubel, 2005)), provokes one to speculate on the possible types of organizations or missions that may have a more pronounced gender-performance variance.

Stahl et al. (2010), in a meta-analysis of 108 empirical studies covering over 10,000 work teams, found that the impact of cultural diversity varied depending on sample characteristics and contextual influences such as team size, team tenure, team dispersion/co-location, and task complexity. For example, cultural diversity was positively correlated with an increased level of conflict when task complexity was high, but insignificant to conflict when task complexity was low. For team tenure, cultural diversity was correlated with higher levels of conflict and less robust communication the longer teams were together.

Page (2007) noted that diversity, when properly grouped, can enhance results in problem-solving settings. However, Page stressed the need for certain conditions, including: a) the problem in question should be difficult; b) participants are smart and possess a high degree of relevant content knowledge; c) contributors represent various backgrounds and have different perspectives; and d) the problem-solving teams are quite large and are selected from a large pool.

In a study of the banking industry, statistical models produced by Richard (2000) yielded neutral or negative results when testing racial diversity with financial performance. However, the paper concluded that racial diversity added value "within the proper context," a context described as involving banks that were currently executing a growth strategy (i.e., already performing well financially). Importantly, the author disclosed that that this was possibly due to reverse causality, implying that high performing banks became more diverse after successful market 
performance.

In a qualitative study of a large U.S. meatpacking firm's board of directors, researchers conceptualized the term "decision diversion," which came about as a result of the changing context of the firm's board of directors and environment (Harvey, Currall \& Hammer, 2017). Contextual changes included the addition of new board members with diverse perspectives (i.e., academicians and labor representatives) and high CEO turnover (three CEOs in five years). The changes were implemented in an effort to improve the performance of the struggling firm, yet they actually inhibited cooperation and decision making. Other contextual elements affecting firm performance and working relationships of board members were dysfunctional senior leadership, a declining agriculture industry, strained management-labor relations, and poor financial results for the firm. Additionally, there were fewer financial reporting regulations at the time of the field observations (Note: data was collected prior to passage of Sarbanes-Oxley legislation), adding to the laxity of management oversight and controls. Given the troubled circumstances of this firm, it may be difficult to generalize these findings to a larger population of organizations. Nevertheless, we believe this type of embedded case study and observational field work are important in the diversity-performance research domain. This methodology permits scholars to recognize context and record phenomena in its natural state.

In a meta-analysis of 68 studies, Schneid et al. (2015) found a negative relationship between gender diversity and contextual performance, which was defined as "activities that contribute to the social network." (p. 733). This analysis also reported that gender egalitarianism (i.e., minimization of gender-role differences while promoting equality) and collectivism had moderating effects on the relationship between gender diversity and task performance. The Schneid et al. (2015) meta-study utilized cultural dimension scoring from the Global Leadership and Organizational Behavior Effectiveness (GLOBE) project (House et al., 2004).

Another contextual influence that may impact organizational or team performance is that of corporate culture. Chatman and Spataro (2005) distinguished between organizational cultures that celebrated individualistic behavior versus a culture that promoted more group-oriented values. The study, which surveyed employees of several different business units of a large multinational financial services firm, found a higher degree of cooperative behavior among relationally different respondents (i.e., diverse in salient ways) in business units characterized as having a more collective culture versus similarly characterized respondents in units scored as having a more individualistic culture.

Foundational work in the field of corporate culture was conducted by Gordon and Cummins (1979) which proposed a model of measurement using the eight dimensions of: action, communication, confrontation, innovation, peopleorientation, planning, results-orientation, and team-orientation. A study by Khosla (2015) used this model in relation to banks in India, testing the correlation of each dimension to profitability. The study found only results-orientation to be statistically significant, with team-orientation having the lowest correlation to profitability. A study by Latif and Ullah (2016), analyzing banks in Pakistan, tested the relationship between corporate "collaboration culture" and performance, finding significance only when internal service quality was the goal.

\section{Great Expectations}

The profit maximization and wealth creation imperatives of capitalism seem to have inclined the behavior of diversity and social justice advocates towards the business case rationale for diversity. The stress of trying to meet such high expectations of better performance as a consequence of diversity may have contributed to the much publicized embellishment of research results.

A recent report from the global consulting firm Ernst \& Young, in an attempt to warn clients of impending quotas 
for corporate boards of large firms in the European Union, includes some reckless claims about diversity dividends. For instance, the report bellows that "The evidence shows that there is a powerful business case for accelerating diversity on boards," and "myriad research confirms that having women on boards improves corporate performance in quantifiable ways," as well as "Groupthink is a very dangerous thing." (Ernst \& Young, 2014). It is not clear, however, how Ernst \& Young's diversity initiatives will counter the threats of groupthink in practice.

An outgrowth of consensus-oriented work groups, the conceptualization of groupthink was popularized by Janis (1972). Interestingly, Janis's symptoms of groupthink included diversity-relevant phenomena such as stereotyping, application of direct pressure on dissidents, and an illusion of morality. Groupthink has been characterized as a convergent process and a negative intermediate team outcome (Stahl et al., 2010). Nevertheless, a common expectation in business circles today is that consensus is a positive result of the decision-making process (Wayne, 2017). Even diverse teams are expected to form a united front, which is an expectation that can squelch dissent and inhibit novel approaches to problems. Surowiecki (2005) finds that "Diversity and independence are important because the best collective decisions are the product of disagreement and contest, not consensus or compromise." (p. 4). Indeed, a meta-analysis by Jackson et al. (2003) reported more benefits from functional diversity when teams were more engaged in debate. Yet even with the promise of access and empowerment of online social media platforms, Klein (2011) notes a tendency of the like-minded to pool together, creating a polarized climate.

Jayne and Dipboye (2004), in a meta-analysis of workplace diversity and performance, acknowledged problems stemming from diversity rhetoric, expectations, and objectives of many corporate diversity programs. Their findings stressed that increased demographic diversity did not correlate with increases in task-related knowledge or skills, commitment, motivation, or group level performance. They also concluded that increased diversity does not necessarily lead to better organizational performance.

Kochan et al. (2003) caution the advocates of the business case rationale with "the simplistic case of the past [for diversity] is simply not supported." Yet their report was clear in its urging of a new way of framing the diversity debate, stating that "while there is no reason to believe diversity will naturally translate into better or worse results, diversity is both a labor market imperative and societal expectation of value." (p. 18). Relatedly, Rhode and Packel (2015) acknowledge the inconsistency of results for the business case of diversity and suggest workplace diversity should be pursued for reasons of reputation and social equity.

In a highly publicized report titled Women at the Wheel (published by Dow Jones, Inc.) a review of over 20,000 venture capital-backed firms resulted in the claim that the proportion of female executives at successful firms was more than double that of unsuccessful firms (7.1\% to 3.1\%) (Canning, Haque \& Wang, 2012). The report also claimed, with statistical significance, that "there is a dependence between a company having female executives and its success." (p. 21). Note, these authors are not just claiming a correlation but are explicitly stating a dependent relationship. It is not until later that the same report, when the entirety of the data set is included, reveals that "In the pool of successful companies versus failed companies, we do not see any significant difference between the proportion of female executives." (p. 32). The report's authors, and the many journalists who retold the highlights of the research, ignored the common problems of halo effects and reverse causality.

Unfortunately, the study of the diversity-performance relationship has devolved, in many cases, into a sloppy truism of sorts. Global consultancies, popular press accounts, and accommodative scholars have taken the "diversity improves performance" maxim as a given without a full reckoning of thoughtful analysis and responsibility (Wayne, 2017). This lack of objectivity is an unfortunate casualty of the boom in diversity research. Problems with expectation bias present themselves from many directions. In a critique of the multicultural movement, Sowell (2013) remarked 
that:

Sweeping claims for the benefits of demographic and cultural diversity in innumerable institutions and circumstances have prevailed without a speck of evidence being asked for or given. It is one of the purest examples of arguments without arguments, and of the force of sheer repetition, insistence and intimidation. (p. 104)

Yet there has been a prodigious amount of evidence gathered in the study of diversity's benefits before and since Sowell's proclamation. And the evidence is equivocal. Perhaps the simplest conclusion to the current diversityperformance debate is a short one. It depends. Encouragingly, scholars have continued to evolve their research designs, diversity constructs, and contextual moderators in order to hone in on more nuanced measures of what matters (and when it matters) in the diversity-performance domain (Harrison \& Klein, 2007; Stahl et al., 2010). We believe this pivoting and adaptability has been healthy and serves to help find meaningful correlations and explanatory criteria, especially given the myriad of contextual situations encountered.

Table 1 provides a summary of notable studies in the diversity-performance domain that were reviewed for this paper.

Table 1: Summary of Selected Diversity-Performance Literature

\begin{tabular}{|c|c|c|}
\hline Author(s)/Year & Study Type and Sample & Key Findings \\
\hline Byron \& Post (2016) & $\begin{array}{l}\text { Meta-analysis of females on } \\
\text { boards and corporate social } \\
\text { performance; } 84 \text { studies. }\end{array}$ & $\begin{array}{l}\text { Female board representation increased social perfor- } \\
\text { mance of firms within the context of operating in coun- } \\
\text { tries with higher gender parity and stronger shareholder } \\
\text { protections. }\end{array}$ \\
\hline Canning et al. (2012) & $\begin{array}{l}\text { Report and data analysis } \\
\text { from over } 20000 \text { venture } \\
\text { capital-backed firms. }\end{array}$ & $\begin{array}{l}\text { No significant difference in rate of business success when } \\
\text { female senior executives are employed. }\end{array}$ \\
\hline $\begin{array}{l}\text { Chatman \& Spataro } \\
(2005)\end{array}$ & $\begin{array}{l}\text { Empirical study of corpo- } \\
\text { rate culture. Several busi- } \\
\text { ness units of large multina- } \\
\text { tional firm. }\end{array}$ & $\begin{array}{l}\text { Higher degree of cooperative behavior found among re- } \\
\text { lationally different respondents in units characterized as } \\
\text { having a more collective culture versus similarly char- } \\
\text { acterized respondents in units scored as having a more } \\
\text { individualistic culture. }\end{array}$ \\
\hline Dezso \& Ross (2012) & $\begin{array}{l}\text { Empirical study of female } \\
\text { top managers and firm per- } \\
\text { formance; } 15 \text { years of panel } \\
\text { data of S\&P } 1500 \text { firms. }\end{array}$ & $\begin{array}{l}\text { Female senior managers positively impact performance } \\
\text { when firms are focused on innovation. Cited "human } \\
\text { capital advantage" of female executives. }\end{array}$ \\
\hline Eagly (2016) & Review and Commentary. & $\begin{array}{l}\text { Slight to no performance effects from female representa- } \\
\text { tion on bards. Recommends that social scientists should } \\
\text { act as "honest brokers" to communicate consensus find- } \\
\text { ings. }\end{array}$ \\
\hline
\end{tabular}


Table 1: Summary of Selected Diversity-Performance Literature

\begin{tabular}{|c|c|c|}
\hline Author(s)/Year & Study Type and Sample & Key Findings \\
\hline Frijns et al. (2016) & $\begin{array}{l}\text { Empirical study of cultural } \\
\text { diversity on boards; } 243 \\
\text { large British firms. }\end{array}$ & $\begin{array}{l}\text { National cultural diversity on boards negatively affected } \\
\text { firm performance. }\end{array}$ \\
\hline $\begin{array}{l}\text { Gomez-Mejia } \quad \& \\
\text { Palich }(1997)\end{array}$ & $\begin{array}{l}\text { Longitudinal study; } 442 \text { For- } \\
\text { tune } 500 \text { firms. }\end{array}$ & $\begin{array}{l}\text { No significant relationship between cultural diversity and } \\
\text { financial performance. }\end{array}$ \\
\hline Harvey et al. (2017) & $\begin{array}{l}\text { Embedded, qualitative case } \\
\text { study of U.S. meatpacking } \\
\text { firm. }\end{array}$ & $\begin{array}{l}\text { Studied numerous contextual factors including diversity } \\
\text { of perspective among board, labor relations, industry } \\
\text { conditions, and CEO turnover. Inconclusive effects on } \\
\text { financial performance. }\end{array}$ \\
\hline Jackson et al. (2003) & $\begin{array}{l}\text { Meta-analysis of top man- } \\
\text { agement teams and organi- } \\
\text { zational diversity; } 63 \text { stud- } \\
\text { ies. }\end{array}$ & $\begin{array}{l}\text { Scant information from studies regarding assessment of } \\
\text { contextual factors. "Little theoretical clarity concerning } \\
\text { how moderators influence the effects of diversity." (p. } \\
816)\end{array}$ \\
\hline $\begin{array}{l}\text { Jayne \& Dipboye } \\
(2004)\end{array}$ & Literature review & $\begin{array}{l}\text { Demographic diversity did not correlate with increases } \\
\text { in task-related knowledge or skills, commitment, motiva- } \\
\text { tion, or group level performance. Found problems with } \\
\text { diversity rhetoric, expectations, and objectives of diver- } \\
\text { sity programs. }\end{array}$ \\
\hline Joshi \& Roh (2009) & $\begin{array}{l}\text { Meta-analysis reviewing } \\
\text { context in work team } \\
\text { diversity; } 39 \text { studies encom- } \\
\text { passing } 8757 \text { teams. }\end{array}$ & $\begin{array}{l}\text { Effects from occupation- and industry-level moderators } \\
\text { were small but consistent in explaining variance across } \\
\text { studies. }\end{array}$ \\
\hline $\begin{array}{l}\text { Julian } \quad \& \quad \text { Ofori- } \\
\text { Dankwa }(2017)\end{array}$ & $\begin{array}{l}\text { Empirical data analysis; } 117 \\
\text { firms from Fortune's "Best } \\
\text { Companies to Work For." }\end{array}$ & $\begin{array}{l}\text { Increasing racial diversity yielded negative effect on firm } \\
\text { productivity. }\end{array}$ \\
\hline $\begin{array}{l}\text { Klein \& Harrison } \\
(2007)\end{array}$ & $\begin{array}{l}\text { Commentary on Diversity } \\
\text { Theorems from Page }(2007)\end{array}$ & $\begin{array}{l}\text { Diversity-performance linkage and logic are less clear } \\
\text { than most think. }\end{array}$ \\
\hline Kochan et al. (2003) & $\begin{array}{l}\text { Study of race, gender and } \\
\text { business performance; Four } \\
\text { large U.S. firms. }\end{array}$ & $\begin{array}{l}\text { Business case for diversity is not supported and should } \\
\text { be modified. }\end{array}$ \\
\hline
\end{tabular}


Table 1: Summary of Selected Diversity-Performance Literature

\begin{tabular}{|c|c|c|}
\hline Author(s)/Year & Study Type and Sample & Key Findings \\
\hline $\begin{array}{l}\text { Mannix \& Neale } \\
(2005)\end{array}$ & $\begin{array}{l}\text { Review of process and ef- } \\
\text { fects of diversity in teams }\end{array}$ & $\begin{array}{l}\text { Surface-level differences are more likely to have negative } \\
\text { effects on group performance; while differences in func- } \\
\text { tional skills, personality, and education tend to improve } \\
\text { group outcomes. Consideration of context and new views } \\
\text { of diversity (e.g., emotions, networks) are stressed. }\end{array}$ \\
\hline Page (2007) & $\begin{array}{l}\text { Theorem development and } \\
\text { testing }\end{array}$ & $\begin{array}{l}\text { Diversity, when properly grouped, enhances problem- } \\
\text { solving under certain conditions. }\end{array}$ \\
\hline Pletzer et al. (2015) & $\begin{array}{l}\text { Meta-analysis focused } \\
\text { on gender and corporate } \\
\text { boards; } 20 \text { studies on } 3097 \\
\text { firms. }\end{array}$ & $\begin{array}{l}\text { Female representation on boards is not related to firms' } \\
\text { financial performance. }\end{array}$ \\
\hline Post \& Byron (2015) & $\begin{array}{l}\text { Meta-analysis of women on } \\
\text { boards and financial perfor- } \\
\text { mance; } 140 \text { studies. }\end{array}$ & $\begin{array}{l}\text { Female board participation increased board's monitoring } \\
\text { and strategy involvement. Concluded that board diver- } \\
\text { sity is neither entirely positive nor negative for firm fi- } \\
\text { nancial performance. }\end{array}$ \\
\hline $\begin{array}{l}\text { Rhode \& Packel } \\
(2015)\end{array}$ & $\begin{array}{l}\text { Review and prescriptive } \\
\text { commentary for corporate } \\
\text { boards. }\end{array}$ & $\begin{array}{l}\text { Mixed results for diversity and performance. Social ob- } \\
\text { jectives should be pursued instead of business case for } \\
\text { diversity. }\end{array}$ \\
\hline Richard (2000) & $\begin{array}{l}\text { Survey of bank HR man- } \\
\text { agers; } 63 \text { banks. }\end{array}$ & $\begin{array}{l}\text { Racial diversity had neutral or negative effects on finan- } \\
\text { cial performance except within the context of banks that } \\
\text { were executing growth strategy. Reverse causality may } \\
\text { be a factor. }\end{array}$ \\
\hline $\begin{array}{l}\text { Sivasubramaniam et } \\
\text { al. (2012) }\end{array}$ & $\begin{array}{l}\text { Meta-analysis of new prod- } \\
\text { uct development team per- } \\
\text { formance; } 38 \text { studies. }\end{array}$ & $\begin{array}{l}\text { Group cohesiveness is an important predictor of team } \\
\text { success. Functional diversity was not significantly related } \\
\text { to team outcomes. }\end{array}$ \\
\hline Schneid et al., (2015) & $\begin{array}{l}\text { Meta-analysis studying im- } \\
\text { pact of gender diversity and } \\
\text { team performance; } 68 \text { em- } \\
\text { pirical studies. }\end{array}$ & $\begin{array}{l}\text { Negative relationship between gender diversity and con- } \\
\text { textual performance. Gender egalitarianism and col- } \\
\text { lectivism moderate the relationship between gender di- } \\
\text { versity and task performance. Authors recommend } \\
\text { adding culture to the CEM model when studying gen- } \\
\text { der diversity-performance relationship. }\end{array}$ \\
\hline
\end{tabular}


Table 1: Summary of Selected Diversity-Performance Literature

\begin{tabular}{|c|c|c|}
\hline Author(s)/Year & Study Type and Sample & Key Findings \\
\hline Stahl et al. (2010) & $\begin{array}{l}\text { Meta-analysis of multicul- } \\
\text { tural work groups; } 108 \text { em- } \\
\text { pirical studies with } 10632 \\
\text { teams. }\end{array}$ & $\begin{array}{l}\text { Cultural diversity leads to process loss due to task con- } \\
\text { flict and weak social integration, but leads to process } \\
\text { gains due to creativity and satisfaction. Effects on cul- } \\
\text { tural diversity are moderated by context (e.g., team size, } \\
\text { dispersion, tenure). }\end{array}$ \\
\hline $\begin{array}{l}\text { Van Dijk et al. } \\
(2012)\end{array}$ & $\begin{array}{l}\text { Review and commentary on } \\
\text { morals versus utilitarian ba- } \\
\text { sis for diversity. }\end{array}$ & Introduced a context-sensitive virtues-ethics approach. \\
\hline $\begin{array}{l}\text { Williams \& O'Reilly } \\
\text { (1998) }\end{array}$ & $\begin{array}{l}\text { Meta-analysis of demogra- } \\
\text { phy diversity in group set- } \\
\text { tings; } 89 \text { studies. }\end{array}$ & $\begin{array}{l}\text { Attributes such as age, tenure, and ethnicity have neg- } \\
\text { ative effects on social integration, communication and } \\
\text { conflict. }\end{array}$ \\
\hline
\end{tabular}

\section{Future Research}

While this paper has largely focused on the equivocal nature of diversity's utilitarian emphasis on performance, our interest in the contextual influences discussed here has not been guided by a single theoretical model nor has it been exclusively focused on just team or organizational performance. Our review and commentary relied, in part, on curiosity and disinterested skepticism. Thus, we are aware of the broad nature of our inquiry and the potential for our own biases to influence the selection of studies to critique. However, we believe future work in this domain may benefit from further application of the categorization-elaboration model (CEM) (Schneid et al., 2015; van Knippenberg et al., 2004). The CEM combines the perspectives of the social categorization theory (Tajfel, 1981) and the information-processing approach (Anacona \& Caldwell, 1992; Mannix \& Neale, 2005; Williams \& O'Reilly, 1998) to better accommodate both positively and negatively hypothesized relationships as well as accounting for moderating influences of context. One problem, however, is that the number and levels of contextual variables and their situations may approach infinity. Future modeling and testing in this area may have to compensate for a proliferation of moderating factors. Importantly, it is theory that will guide what is measured going forward.

We are also encouraged a model of diversity context from Joshi and Roh (2013) that posits a tripartite schema which includes structural, relational, and narrative elements. Structural components of the diversity context include the overall heterogeneity of the organization and the level of structural integration of minority groups. Relational diversity context involves social capital, trust, and patterns of interactions. And lastly, the normative diversity context encompasses the organizational culture, management practices, and expected behaviors of members.

Regardless of the direction of the statistically significant results in diversity-performance research, our review has confirmed the explanatory power of the results is often quite weak (Eagly, 2016; Joshi \& Roh, 2009; Schneid et al. 2015). In the future, scholars should be mindful of how context may impact their assumptions and research 
designs. Johns (2006) notes how context is likely responsible for much of the "study-to-study variation in research findings," and points out that "context will often vary more than individual differences across research sites." (p. 389). He also provides helpful caveats for future research, elaborating on how context influences research results by: restricting observational range; affecting base rates of key variables; changing causal direction; reversing correlational signs; instigating curvilinear effects; dramatically (though with subtlety) tipping "precarious relationships;" and threatening study validity and generalizability (Johns, 2006).

Early in this paper we included a foundational review of some traditional cultural frameworks. The intent of this was to show the inherent linkages, we believe, to new values-based approaches being developed that attempt to explain the complexities of the diversity-performance relationships within a multitude of conditions.

For example, we believe the values, schemas, and norms framework developed by Leung and Morris (2015) offers a promising model to study explanatory power of specific contexts and situations impacting the diversityperformance relationship. This leads us to ponder additional theory and model development. For example, while employing cultural and diversity attributes as a foundation, we envision a model that may include a quantifiable "sameness-otherness continuum," with a variety of contextual moderators and mediating variables (e.g., type of diversity/inclusion management programs, diversity climate, organization type or size, industry conditions, personality types, job complexity, etc.) with outcomes related to team and organizational performance as well as measures for economic and social justice. Near term we see many opportunities for topographical and propositional developments related to this conceptualization. We contend that the much anticipated performance-related value of diversity may lie in context-dependent relationships.

Additionally, we offer several potential research questions and considerations for study. Given the inconsistency of results in the study of diversity and performance, is there a need for more interdisciplinary research in this domain? Perhaps diversity research should adhere to more stringent disclosure of conflicts of interests. And how will the future of diversity research incorporate the rapid pace of technology? For instance, as artificial intelligence and robotics continue to advance, how will scholars include these factors in workplace diversity research? If candidate selection and promotion decisions become more automated in the future, how will algorithms value or even disregard certain characteristics of candidates? To what extent will a less-human human resource department stereotype or exhibit biased thinking based on rules coded by programmers - or coded by itself via machine learning?

How are first line supervisors, project team leaders, middle managers, and senior management teams expected to deal with such complex and often conflicting diversity initiatives? How are these decision makers to view a continuing barrage of headlines and marketing materials that hail the "undisputed" benefits of diversity-especially given that much of the scholarship literature tells a different story? And how can diversity-performance researchers more actively study employees of lower, less visible levels of organizational hierarchies?

\section{Conclusions}

Admittedly, we are still perplexed as to what scholars and practitioners are to make of the business case prerogative for diversity. Will a "happy medium" emerge where the productivity demands of capitalism harmoniously coexist with the goals of equality and social justice advocates? We view the efforts of equality advocates as analogous, in part, to the zeal exhibited by environmentalists when pushing for the adoption of "green" technology. The business case of lowering costs by investing in new, more efficient energy systems for a factory or hotel offers a clear imperative that results in better performance (i.e., lower costs). This makes it easy for firms to switch to cleaner energy and behave 
in a principled manner even if decision makers are not particularly environmentally conscious. The business case for diversity, however, has proven to be more difficult to make. This does not mean that organizations should abandon diversity and inclusion programs. There are often societal benefits that can be embraced and communicated with positive public relations. Similar to proactive Corporate Social Responsibility (CSR) programs and Environmental Social Governance (ESG) initiatives, diversity efforts may signal beneficial motives to stakeholders that do not, per se, result in measurable increases in shareholder returns. Advocates for more women on boards, for example, may be pleased with the social justice aspects of more equal representation by gender. However, the business case (i.e., better organizational performance) should not be conjured up in situations where it does not exist. Hypotheses aimed at showing "no difference" in performance as a result of diversity may be better suited than more ambitious predictions seeking superior performance outcomes. Pragmatically speaking, why should traditionally studied characteristics like gender, race, or ethnicity matter-especially within a common geo-national culture-with regard to performance. Are not most top level managers intelligent, well-trained, qualified, ambitious, and politically savvy individualsregardless of their gender, race, or ethnicity?

Diversity is not a magic bullet, and thus should not be presented as such. We believe that scholars should refrain from terminology such as "disappointed" and "unfortunately" when discussing research results that do not support hypothesized, positive relationships between diversity and performance-regardless of the specific type of diversity being studied. Left unchecked, passion and advocacy for a cause or desired result will impede the fundamental responsibilities of management scholars - which are the discovery, testing, re-testing and truthful explanation of knowledge.

\section{References}

Ancona, D. \& Caldwell, D., 1992. Demography \& Design: Predictors of New Product Teams Performance. Organization Science, 3:321-341.

$\mathrm{Au}, \mathrm{K} ., 1999$. Intra-cultural Variation: Evidence and Implications for International Business. Journal of International Business Studies, 30(4): 799-812.

Berrey, E., 2015. The Enigma of Diversity: The Language of Race and the Limits of Racial Justice. Chicago: University of Chicago Press.

Brannen, M. \& Salk, J., 2000. Partnering Across Borders: Negotiating Organizational Culture in a German-Japanese Joint Venture. Human Relations, 53(4): 451-487.

Byrne, D., 1971. The Attraction Paradigm. New York: Academic Press.

Byron, K. \& Post, C., 2016. Women on Boards of Directors and Corporate Social Performance: A Meta-analysis. Corporate Governance: An International Review, 24(4): 428-442.

Canning, J., Haque, M. \& Wang, Y., 2012. Women at The Wheel: Do Female Executives Drive Start-up Success? New York: Dow Jones \& Company. Retrieved June 20, 2016 from http://www.dowjones.com/privatemarkets/ pm_download.asp.

Chatman, J. \& Spataro, S., 2005. Using Self-categorization Theory to Understand Relational Demography-based Variations in People's Responsiveness to Organizational Culture. Academy of Management Journal, 48(2): 321331.

Cowen, T., 2002. Creative Destruction: How Globalization is Changing the World's Cultures. New York: Basic Books. Dezso, C. \& Ross, D., 2012. Does Female Representation in Top Management Improve firm Performance? A Panel 
Data Investigation. Strategic Management Journal, 33: 1072-1089.

Dobbin, F. \& Kalev, A., 2016. Why Diversity Programs Fail: And What Works Better. Harvard Business Review, Jul-Aug, pp. 52-60.

Eagly, A., 2016. When Passionate Advocates Meet Research on Diversity, Does The Honest Broker Stand a Chance? Journal of Social Issues, 72: 199-222. doi:10.1111/josi.12163

Egan, M. \& Bendick, M., 2008. Combining Multicultural Management and Diversity into One Course on Cultural Competence. Academy of Management Learning and Education, \%: 387-393.

Ernst \& Young, 2014. Time for Diversity: Accelerating Performance in Europe's Boardrooms. Retrieved October 1, 2017 from http://www.ey.com/Publication/vwLUAssets/EY_Time_for_diversity/\$FILE/EY-WoB-Time-fordiversity.pdI

Estelyi, K. \& Nisar, T., 2016. Diverse Boards: Why Do Firms Get Foreign Nationals on Their Boards? Journal of Corporate Finance, 38: 174-192.

Frijns, B., Dodd, O. \& Cimerova, H., 2016. The Impact of Cultural Diversity in Corporate Boards on Firm Performance. Journal of Corporate Finance, 41: 521-541.

Goby, V., 1999. All Business Students Need to Know The Same Things! The non-culture-specific nature of communication needs. Journal of Business and Technical Communication, 13 (2):179-189.

Gomez-Mejia, L. \& Palich, L., 1997. Cultural Diversity and The Performance of Multinational Firms. Journal of International Business Studies, 28(2): 309-335.

Gordon, G. \& Cummins, W., 1979. Managing Management Climate. Lexington, MA: Lexington Books.

Green, J., 2017. Where Minority Worker Networks Are Passé. Bloomberg Businessweek, July 24, 2017, p. 15-16.

Harrison, D. \& Klein, K., 2007. What's The Difference? Diversity, Constructs as Separation, Variety, or Disparity in Organizations. Academy of Management Review, 32(4):1199-1228.

Harvey, S., Currall, S. \& Hammer, T., 2017. Decision Diversion in Diverse Teams: Findings From Inside A Corporate Boardroom. Academy of Management Discoveries, 3(4): 358-381.

Hofstede, G., 1980. Culture's Consequences: International Differences In Work-related Values. Beverly Hill: Sage Publications.

Hofstede, G., 1993. Cultural Constraints in Management Theories. Academy of Management Executive, 7: 81-94.

Hofstede, G., 1999. Problems Remain, But Theories Will Change: The Universal and The Specific in 21st-Century Global Management. Organizational Dynamics, 28(1): 34-44.

Hofstede, G., 2001. Culture's Consequences: Comparing Values, Behaviors, Institutions and Organizations across Nations. Thousand Oaks, CA: Sage.

Hofstede, G., Hofstede, G. J. \& Minkov, M., 2010. Culture and Organizations: Software of The Mind: Intercultural Cooperation and Its Importance for Survival. New York: McGraw-Hill.

Hogg, M. \& Abrams, D., 1988. Social Identification. London: Routledge.

House, R., Hanges, P., Javidan, M., Dorfman, P. \& Gupta, V., 2004. Culture, Leadership, and Organizations: The GLOBE Study of 62 Societies. Thousand Oaks, CA: Sage.

Hsu, T., 2012. Women on Board: Firms with Female Directors Do Better, Study Says. Los Angeles Times. Retrieved on Oct. 1, 2017 from http://articles.latimes.com/2012/aug/01/business/la-fi-mo-women-boardperformance-20120801.

Hunt, V., Layton, D. \& Prince, S., 2015. Diversity Matters. McKinsey \& Company. Retrieved January 16, 2016 from http://www.mckinsey.com/Insights/Organization/Why_diversity_matters 
INSEAD, 2008. Diversity Is Not Diversity. INSEAD Knowledge, July 8, 2008. Retrieved July 1 , 2017 from https://knowledge.insead.edu/leadership-management/talent-management/diversity-is-notdiversity-is-not-diversity-2089

Jackson, S., Joshi, A. \& Erhardt, N., 2003. Recent Research on Team and Organizational Diversity: SWOT Analysis and Implications. Journal of Management, 29: 801-830.

Janis, I., 1972. Victims of Groupthink: A Psychological Study of Foreign-policy Decisions and Fiascos. Boston: Houghton Mifflin.

Jayne, M. \& Dipboye, R., 2004. Leveraging Diversity to Improve Business Performance: Research Findings and Recommendations for Organizations. Human Resource Management, 43(4): 409-424.

Johns, G., 2006. The Essential Impact of Context on Organizational Behavior. Academy of Management Review, 31(2): 386-408.

Joshi, A. \& Roh, H., 2009. The Role of Context in Work Team Diversity Research: A Meta-analytic Review. Academy of Management Journal, 52(3): 599-627.

Joshi, A. \& Roh, H., 2013. Understanding How Context Shapes Team Diversity Outcomes. In Roberson, Q. (Ed.) The Oxford Handbook of Diversity and Work, p. 209-219. New York: Oxford University Press.

Julian, S. \& Ofori-Dankwa, J., 2017. Context Matters: Diversity's Short- and Long-term Effects in Fortune's 'Best Companies to Work for.' Strategic Management Journal, 38: 1557-1565.

Kalev, A., Kelly, E. \& Dobbin, F., 2006. Best Practices or Best Guesses? Assessing The Efficacy of Corporate Affirmative Action and Diversity Policies. American Sociological Review, 71:589-617.

Khosla, A., 2015. Impact of Organizational Culture on Organizational Performance. Journal of Institute of Public Enterprise, 38(1\&2): 150-164.

Kivenzor, G., 2015. Cultural Dynamics and Marketing Strategies for Emerging Markets: Characterizations of Group Subcultures and Consumption Preferences. AMS Review, 5(3):142-158.

Klein, M., 2011. How to Harvest Collective Wisdom and Complex Problems: An Introduction to the MIT Deliberatorium. MIT Center for Collective Intelligence. Retrieved July 28, 2015 from http://cci.mit.edu/klein/ deliberatorium.htm $\perp$

Klein, K. \& Harrison, D., 2007. On the Diversity of Diversity: Tidy Logic, Messier Realities. Academy of Management Perspectives, 21(4): 26-33.

Kochan, T., Bezrukova, K., Ely, R., Jackson, S., Joshi, A., Jehn, K., Leonard, J., Levine, D. \& Thomas, D., 2003.

The Effects of Diversity on Business Performance: Report of the Diversity Network. Human Resource Management, 42(1):3-21.

Kristof-Brown, A., Zimmerman, R. \& Johnson, E., 2005. Consequences of Individuals' Fit at Work: A Meta-analysis of Person-organization, Person-group and Person-supervisor fit. Personnel Psychology, 58(2): 281-342.

Latif, K. \& Ullah, M., 2016. An Empirical Investigation into the Relationship between Organizational Culture, Internal Service Quality (ISQ) and Organizational Performance. Abasyn Journal of Social Sciences, 9(1): 31-52.

Lenartowicz, T. \& Roth, K., 1999. A Framework for Cultural Assessment. Journal of International Business Studies, 30(4): 781-799.

Leung, K. \& Morris, M. W., 2015. Values, Schemas, and Norms in the Culture-behavior Nexus: A Situated Dynamics Framework. Journal of International Business Studies, 46(9): 1028-1050.

Mannix, E. \& Neale, M., 2005. What Differences Make a Difference? The Promise and Reality of Diverse Teams in Organizations. Psychological Sciences in the Public Interest, 6(2): 31-55.

Journal of Management and Training for Industries, Vol.5, No.3, 2018 
Mims, C., 2017, Aug 14. Making a Business Case for Diversity. Wall Street Journal, p. B1, 4.

Morris, M., Williams, K., Leung, K. \& Larrick, R., 1998. Conflict Management Style: Accounting for Cross-national Differences. Journal of International Business Studies, 29(4): 729-747.

Newcomb, T., 1961. The Acquaintance Process. New York: Holt, Rinehart, and Winston.

Newman, K. \& Nollen, S., 1996. Culture and Congruence: The Fit between Management Practices and National Culture. Journal of International Business Studies. 27(4): 753-779.

Page, S., 2007. Making the Difference: Applying a Logic of Diversity. Academy of Management Perspectives, 21(4): $6-20$.

Pfeffer, J., 1983. Organizational demography. In B. Straw and L. Cummings (Eds.), Research in Organizational Behavior, 5: 299-357. Greenwich, CT: JAI Press.

Pletzer, JL, Nikolova, R., Kedzior, K. \& Voelpel, S., 2015. Does Gender Matter? Remale Representation on Corporate Boards and Firm Financial Performance - A Meta-analysis. PLoS One, 10(6). doi:10.1371/journal.pone.0130005

Post, C. \& Byron, K., 2015. Women on Boards and Firm Financial Performance: A Meta-analysis. Academy of Management Journal, 58(5): 1546-1571.

Rhode, D. \& Packel, A., 2015, Feb. Director Notes: Diversity on Corporate Boards: How Much "Difference" Does Difference Makes? The Conference Board, No. DN-V7N2. Retrieved July 28, 2016 from www.conferenceboard.org/director notes.

Richard, O., 2000. Racial Diversity, Business Strategy, and Firm Performance: A Resource-based View. Academy of Management Journal, 43(2): 164-177.

Sacco, J. \& Schmitt, N., 2005. A Dynamic Multilevel Model of Demographic Diversity and Misfit Effects. Journal of Applied Psychology, 90(2): 203-231.

Schneid, M., Isidor, R., Li, C. \& Kabst, R., 2015. The Influence of Cultural Context on the Relationship between Gender Diversity and Team Performance: A Meta-analysis. The International Journal of Human Resource Management, 26(6): 733-756.

Schuler, R. \& Rogovsky, N., 1998. Understanding Compensation Practice Variations Across Firms: The Impact of National Culture. Journal of International Business Studies, 29(1):159-177.

Schwartz, S. H., 1999. A Theory of Cultural Values and Some Implications for Work. Applied Psychology, 48(1): 23-47.

Schwartz, S. H., 2006. A Theory of Cultural Value Orientations: Expectations and Applications. Comparative Sociology 5(2-3): 137-182.

Schwartz, S. H. \& Rubel, T., 2005. Sex Difference in Value Priorities: Cross-cultural and Multimethod Studies. Journal of Personality and Social Psychology, 89(6): 1010-1028.

Sivasubramaniam, N., Liebowitz, S. \& Lackman, C., 2012. Determinants of New Product Development Team Performance: A Meta-analytic Review. Journal of Product Innovation Management, 29(5): 803-820.

Sowell, T., 2013. Intellectuals and Race. New York: Basic Books.

Stahl, G., Maznevski, M., Voigt, A. \& Jonsen, K., 2010. Unraveling the Effects of Cultural Diversity in Teams: A Meta-analysis of Research on Multicultural Work Groups. Journal of International Business Studies, 41: 690-709. Surowiecki, J., 2005. The Wisdom of Crowds. New York: Anchor Books.

Tajfel, H., 1981. Human Groups and Social Categories: Studies in Social Psychology. Cambridge, England: Cambridge University Press. 
Taras, V., Steel, P. \& Kirkman, B., 2016. Does Country Equate with Culture? Beyond Geography in the Search for Cultural Boundaries. Management International Review, 56(4): 455-487.

Turner, J., 1985. Social Categorization and the Self Concept: A Social Cognitive Theory of Group Behavior. Advances in Group Processes (Vol. 2, pp. 77-121). Greenwich, CT: JAI Press.

van Dijk, H., van Engen, M. \& Paauwe, J., 2012. Reframing the Business Case for Diversity: A Values and Virtues Perspective. Journal of Business Ethics, 111: 73-84.

van Knippenberg, D., De Dreu, C. \& Homan, A., 2004. Work Group Diversity and Group Performance: An Integrative Model and Research Agenda. Journal of Applied Psychology, 89: 1008-1022.

van Knippenberg, D. \& Schippers, M., 2007. Work Group Diversity. Annual Review of Psychology, 58: 515-541. van Knippenberg, D., van Ginkel, W. \& Homan, A., 2013. Diversity Mindsets and the Performance of Diverse Teams. Organizational Behavior and Human Decision Processes, 121: 183-193.

Wayne, K., 2017. Deconstructing Management Maxims: A Critical Examination of Conventional Business Wisdom, Volumes I \& II. New York: Business Expert Press.

Wharton School, 2017, May 18. Does Gender Diversity on Boards Really Boost Company Performance? Knowledge @ Wharton online journal. Retrieved on June 9, 2017 from http://knowledge.wharton.upenn.edu/article/ will-gender-diversity-boards-really-boost-company-performance/?utm_source=kw_newsletter\&utm_ medium=email\&utm_campaign=2017-0b-18

Wharton School, 2016, Mar 24. 'Gender Equality by Design': Building a More Inclusive (and Productive) Workplace. Knowledge@Wharton online journal. Retrieved March 26, 2016 from http://knowledge.wharton. upenn.edu/article/gender-equality-design-building-inclusive-productive-workplace/?utm_source= kw_newsletter\&utm_medium=email\&utm_campaign=2016-03-24

Williams, K. \& O'Reilly, C.A., 1998. Demography and Diversity: A Review of 40 Years of Research. In B. Staw and R. Sutton (Eds.) Research in Organizational Behavior, 20: 77-140. Greenwich, CT: JAI Press.

Zanoni, P., 2014. Critical Perspectives on Diversity: State of the Art and Promising Avenues for Future Research. Sociologia del Lavoro, 134: 189-203.

Journal of Management and Training for Industries, Vol.5, No.3, 2018 